\title{
The Influence of Marketing and The Quality of Service to The Visitor Loyalty in Fashion Products
}

\author{
Atikha Sidhi Cahyana \\ Fakultas Teknik \\ Universitas Muhammadiyah Sidoarjo \\ Sidoarjo, Indonesia \\ atikhasidhi@umsida.ac.id
}

\author{
Dadang Sukoriyono \\ Fakultas Teknik \\ Universitas Muhammadiyah Sidoarjo \\ Sidoarjo, Indonesia \\ dadang.soekoriyono@gmail.com
}

\begin{abstract}
PT. Matahari Department Store always strives to provide services and products that can satisfy loyal customers, the cause of this problem is less consistent in the implementation of service standards by employees, there are several causes that affect the quality of each service provided by employees, the company's management has attempted to accommodate this problem with independent teams assessing the quality of service employees, and the results are still short, the very high level of competition in the retail service industry poses challenges for every department store to determine an effective and consistent marketing strategy to sustain and attract visitor loyalty, expectations in this regard can be achieved if the marketing strategy can be implemented effectively and consistent service quality and continue to improve. This study examines the indicators that affect the ability of visitor loyalty in fashion products, to illustrate how big influence, this research using Structural Equation Modeling approach. Based on the result of $t-$ value, shows that the significant variables are $\mathrm{H1}=$ marketing positively influence to loyalty, $\mathrm{H} 2$ = marketing has positive effect on service quality, $\mathrm{H3}$ = service quality positively influence to loyalty. The results are all hypotheses significant or have a positive relationship.
\end{abstract}

Keywords— quality of service; loyalty; marketing

\section{INTRODUCTION}

The lifestyle of modern society will be the need for a fashion product as well as casual wear, Formal clothes, shoes, sandals, accesories, cosmetic and other fashion needs become very complex. The desire of the community is not only the substance of the collection of Fashion products but accompanied by the element of service, the feel of classy with luxury display settings that seem luxurious, as well as the arrangement of comfortable space, clean, fragrance and neat and interesting merchandise, not only that people also want security when shopping. One type of retail company that provides fashion products that fit the characteristics are department stores. Likewise with PT. Matahari Department Store Lippo Plazza Sidoarjo always trying to provide services and products that can satisfy its loyal customers, Not infrequently also every company engaged in services in the presence of problems of service quality that exist in the company, so it can cause loss for the company and also employees, the cause of this problem is less consistent in the application of service standards by the employees themselves, there are several causes that affect the quality of each service provided by employees, the management company has attempted to accommodate this problem with the independent team that assessing quality employee service, in still there is less implementation of quality service by employees, the level of competition is very high in the retail service industry poses a challenge for every department store to determine the effective marketing strategy and consistent to be able to maintain and attract visitor loyalty, expectations in this case can be achieved if the marketing strategy can be implemented effectively and consistent service quality and continue to improve.

In the development of the business world today provides the potential for retailers who are in the market, especially large retailers with increased consumption of people's desire in shopping to make this business increasingly in demand by business people, retail taken from the French word retailers ie meaning "cut into small - small" [1]. Retailing is a retail sale based on the overall activity that involves selling the product or service to the last consumer for personal use rather than business purposes [2].

\section{METHODS}

Research conducted will lead to an analysis of the search for the relationship between the variables in the model built. The method used to confirm these relationships is Structural Equation Modeling (SEM). This research was conducted to examine the theoretical relationship between the influence of Marketing and Service Quality on Visitor Loyalty, to describe how much influence, this research uses Structural Equation Modeling approach.

The type of data used in this study is the primary data. Primary data is data that is still raw (no treatment on the data) and obtained with the collector's directly by the researchers. Primary data of this research will be obtained from survey results, in the form of respondents' answers to the questions related to the purpose of the study. The survey was conducted with two methods, namely direct interview and questionnaire delivery to the respondents.

Respondent from this research is consumer of PT. Matahari Department Store Lippo Plazza Sidoarjo, Indonesia. The minimum sample size taken in this study was based on 
Hair et al's suggestion that the appropriate sample size for SEM analysis depends on the number of indicators multiplied by five to ten. In accordance with the number of indicator variables, the minimum sample size in this study was $13 \times 10$ $=130$ samples. In the category of respondents with the amount of data less than 200 samples, it will be additional data in that category [3].

\section{A. Research Hypothesis}

The components modeling model will be tested through a series of hypotheses with the SEM process. The hypothesis of the research explains one by one hypothesis obtained from previous research related to To facilitate the processing of data in the next, then made the research framework or structural model of research as in Figure 1. The function of the structural model of the researchers is to see the relationship between each varia- bell and explain the relationship between one variable with another variable.

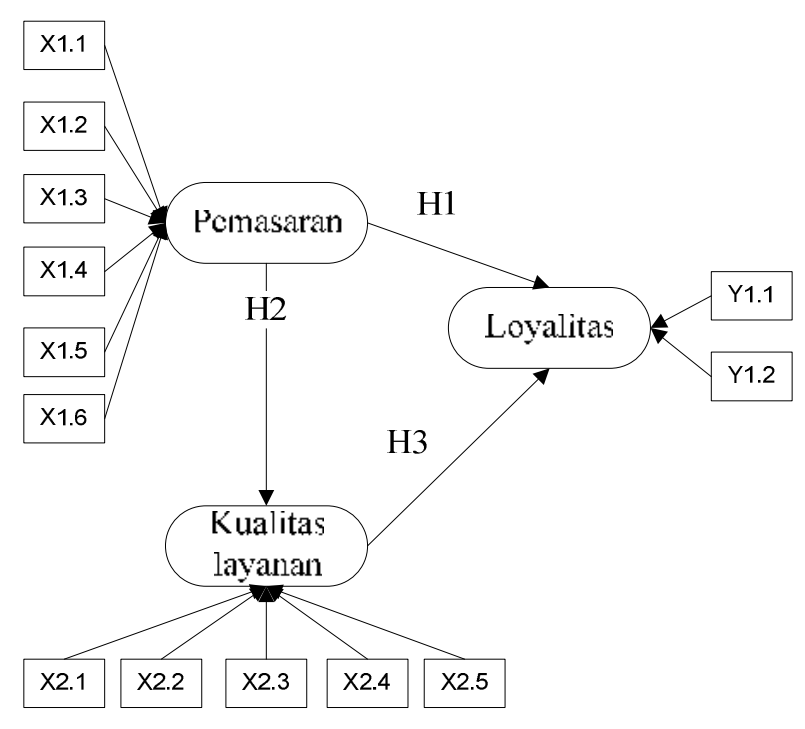

Fig. 1. Structural model of research

As for referring to the relationship of these variables obtained hypotheses as follows:

Hypothesis1 = Marketing has a positive effect on Loyalty [4][5]

Hypothesis 2 = Marketing has a positive effect on Service Quality [4][5][6]

Hypothesis 3 = Service quality positively affects Loyalty [5]

\section{RESULT AND DISCUSSION}

Testing the validity of data is done by correlating between the score of items with the total score of variables that have been correlated. The high correlation coefficient indicates the suitability between the item score and the total score of the corrected variable. The high correlation coefficient indicates the suitability between the item fun and the overall research variable. Data tested as many as 30 respondents using spss 16. Based on Masrun when the correlation coefficient is positive and the value is greater than
0.3 then the indicator concerned is considered valid [7]. The analysis technique used is Product Moment Pearson's chorelation. In the test the validity value can be seen from the value of Corrected item-total correlation, all the indicators involved in the questionnaire show a value above 0.3 which means that all the indicators involved are valid so that it can be used for the next survey.

Structural model testing is done by involving all variables that have been tested in the measurement model one by one. The result of structural testing of the complete model along with the value of goodness of fit can be seen in Figure 2 .

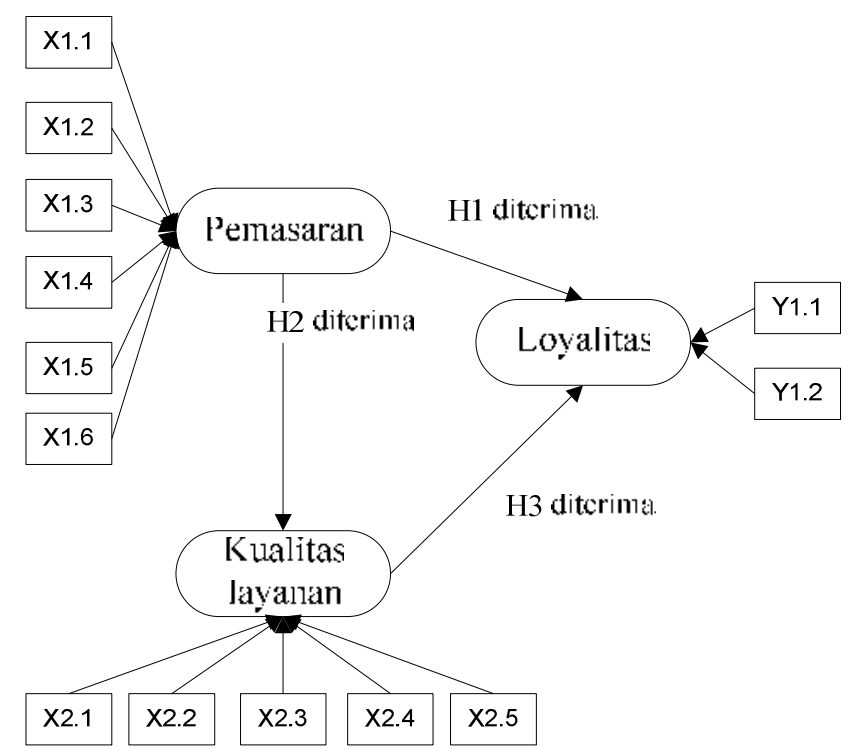

Fig. 2. Conceptual model of research

Based on the hypothesis that has been built and the results of hypothesis testing research, obtained results as shown in Table I.

\begin{tabular}{|l|l|l|}
\hline \multicolumn{1}{|c|}{ Hypothesis } & \multicolumn{1}{|c|}{ Hypothesis } & \multicolumn{1}{c|}{ Results } \\
\hline Hypothesis 1 & $\begin{array}{l}\text { Marketing has a } \\
\text { positive effect on } \\
\text { Loyalty }\end{array}$ & Significant / Acceptable \\
\hline Hypothesis 2 & $\begin{array}{l}\text { Marketing has a } \\
\text { positive effect on } \\
\text { Loyalty }\end{array}$ & Significant / Acceptable \\
\hline Hypothesis 3 & $\begin{array}{l}\text { Service quality has a } \\
\text { positive effect on } \\
\text { Loyalty }\end{array}$ & Significant / Acceptable \\
\hline
\end{tabular}

TABLE I. HYPOTHESIS TEST RESULT

\section{CONCLUSION}

Based on the data analysis done and the purpose of the research can be drawn the following conclusions: (1) this study analyzes the relationship of variables namely the influence of Marketing And Service Quality Against Visitor Loyalty; (2) increased loyalty of visitors can be done by (a) providing many choices and art of arrangement of goods include models, colors, and the latest collection of fashion products as supporting the lifestyle of customers, (b) offering prices in accordance with the purchasing power of the 
surrounding community, (c) providing extensive parking and a wide availability of sales areas, (d) providing promo information through electronic media and mass media and providing additional discounts for Sun member card holders, (e) providing product quality assurance to customers, (f) describing the inadequacy of products offered by the sun as well as acceptable to customers by giving a positive impression, $(\mathrm{g})$ the professionalism of all shop employees in the totality of work, (h) describing the accuracy and speed of payments in the checkout area, (i) the company's concern for the convenience of customers in shopping for fashion products.

\section{ACKNOWLEDGEMENT}

Thank you to Universitas Muhammadiyah Sidoarjo and PT. Matahari Department Store Lippo Plazza Sidoarjo for supporting this research.

\section{REFERENCES}

[1] Risch, Ernest, H., Retail Merchandising : Concepts, Dynamic and Applications, First Edition, Merril Publishing Company, 2013.

[2] Kotler Philip, dan Gary Amstrong, Principles Of Marketing, Global Edition, 14 Edition, Pearson Education, 2012.

[3] Hair, J. F, Black W. C, and Babin, B.J, Multivariate Data Analysis, 7th Edition, Prentice Hall, Inc, 2009.

[4] Lodhita, Eka Heru Santoso, Imam, Sakuda Anggraini, Analisis Pengaruh Kualitas Pelayanan Terhadap Kepuasan Konsumen Menggunakan Metode IPA (Importance Performance Analysis) dan CSI (Customer Satisfaction Index) toko Oen, jurnal TI Universitas Brawijaya Malang, 2013.

[5] Vaula, Siendy Tito, Dania, Prima Agustin Wike. Effendi, Usman., Analisis Persepsi Konsumen Terhadap Ekuitas Merek Menggunakan Metode SEM (Structural Equation Modelling) , Jurnal TI Universitas Brawijaya Malang, 2012.

[6] William, J. Dan Aitken., The Service- Dominant Logic of Marketing and Marketing Ethict, journal of Bussines Ethict, Vol, 102 pp. 439 454, America, 2012.

[7] Masrun, Reliabilitas dan Cara Menentukannya, Universitas Gajah Mada, 1979. 